\title{
Suppressor of cytokine signaling and accelerated atherosclerosis in kidney disease
}

\author{
Joanna Wesoly ${ }^{1}$, Krzysztof Sikorski', Chien-Kuo Lee ${ }^{2}$ and Hans A. R. Bluyssen ${ }^{1 凶}$ \\ 'Laboratory of Human Molecular Genetics, Institute of Molecular Biology and Biotechnology, Faculty of Biology, University of Adam Mickiewicz, \\ Poznań, Poland; ${ }^{2}$ The Graduate Institute of Immunology, National Taiwan University College of Medicine, Taipei, Taiwan
}

The prevalence of cardiovascular disease in patients with renal failure is extremely high and accounts for a large part of the morbidity and mortality. Inflammation participates importantly in host defense against infectious agents and injury, but also contributes to the pathophysiology of many diseases, including cardiovascular atherosclerosis, which is a main problem in patients with renal failure. Recruitment of blood leukocytes to the injured vascular endothelium characterizes the initiation and progression of atherosclerosis and involves many inflammatory mediators, modulated by cells of both innate and adaptive immunity. Excessive inflammatory and immune responses, communicated by these different cell types, are driven by inflammatory cytokines that promote associated tissue damage if cytokine signaling pathways remain unregulated. Thus, pathways capable of suppressing proinflammatory cytokine signaling hold the potential to limit life-threatening cardiovascular events caused by atherogenesis. Suppressor of cytokine signaling (SOCS) are a family of intracellular proteins, several of which have emerged as key physiological regulators of cytokine-mediated homeostasis, including innate and adaptive immunity. Accumulating evidence supports the idea that dysregulation of cytokine signaling by differential SOCS expression is involved in the pathogenesis of various inflammatory, and immunological diseases, including atherosclerosis. Based on recent observations, in which SOCS expression levels are profoundly altered in kidney disease, we discuss the possibilities of SOCS as new intracellular markers of inflammation as well as their potential atherogenic properties in renal failure related cardiovascular disease.

Keywords: kidney disease, inflammation, atherosclerosis, SOCS Received: 14 June, 2010; revised: 17 July, 2010; accepted: 19 July, 2010; available on-line: 19 August, 2010

\section{INTRODUCTION}

Chronic renal failure (CRF) is a clinical syndrome associated with a slow decline in kidney function over time. CRF may be caused by a number of disorders, which include long-standing hypertension, diabetes, glomerulonephritis and congenital kidney disease. If renal function declines below a certain level (glomerular filtration rate $<15 \mathrm{ml} / \mathrm{min}$ per $1.73 \mathrm{~m}^{2}$ ) patients enter the end stage renal disease (ESRD) phase in which renal replacement therapy using dialysis may be necessary. The ultimate cure for these patients is kidney transplantation.
The prevalence of atherosclerotic cardiovascular disease (CVD) in patients with CRF is extremely high and accounts for a large part of the morbidity and mortality in this group (Roberts et al., 2006). In ESRD patients $60 \%$ of mortality is caused by atherosclerosis (Levey et al., 1998). In addition to traditional risk factors (e.g. hypertension and dyslipidemia) (Chan, 2005; Roberts et al., 2006), CRF forms an independent risk factor for CVD. Somehow, a decrease in renal clearance and neurohumoral consequences of renal disease aggravate the atherosclerotic process (Mathur et al., 2002; Stenvinkel et al., 2003). Increased oxidative stress and inflammation, both common features of CRF and ESRD, are considered central in the pathogenesis and may contribute to the accelerated atherosclerosis.

Strong evidence is emerging that management of inflammation could substantially decrease prevalence of CVD (Kwak et al., 2003; Hansson et al., 2006), pointing to the importance of molecules that are able to diminish or inhibit inflammation. Currently no recognized or even proposed treatment exists for renal patients with chronic inflammation (Stenvinkel, 2002), stressing the importance to identify new possibilities to manage inflammation in patients with renal failure. Better understanding of the molecular and clinical mechanisms of inflammation could therefore help to provide new therapeutical strategies to control inflammation and consequently atherosclerotic CVD in renal patients.

\section{ATHEROSCLEROSIS AND INFLAMMATION}

The normal arterial endothelium resists prolonged contact with leukocytes, including monocytes and lymphocytes. Recruitment of blood leukocytes to the injured vascular endothelium characterizes the initiation and progression of atherosclerosis and involves a variety of inflammatory mediators, modulated by cells of both innate and adaptive immunity (Libby,

\footnotetext{
$\triangle$ e-mail: johannes.bluijssen@amu.edu.pl
}

Abbreviations: CIS, cytokine-induced SH2-containing protein; CRF, chronic renal failure; CRP, C-reactive protein; CVD, cardiovascular disease; EC, endothelial cells; ESRD, end stage renal disease; EPO, erythropoietin; IGF-1, insulin growth factor 1; IFN, interferon; $\mathrm{IL}$, interleukin; IRS, insulin receptor substrate; G-CSF, granulocyte colony-stimulating factor; $\mathrm{GH}$, growth hormone; JAK, Janus kinase; KIR, knase inhibitory domain; KO, knockout; LPS, lipopolysaccharide; PBMC, peripheral blood mononuclear cells; SOCS, suppressor of cytokine signaling; SMC, smoth muscle cell; STAT, signal transducer and activator of transcription; Th, T-helper cell; TNF, tumor necrosis factor; VSMC, vascular smooth muscle cell 


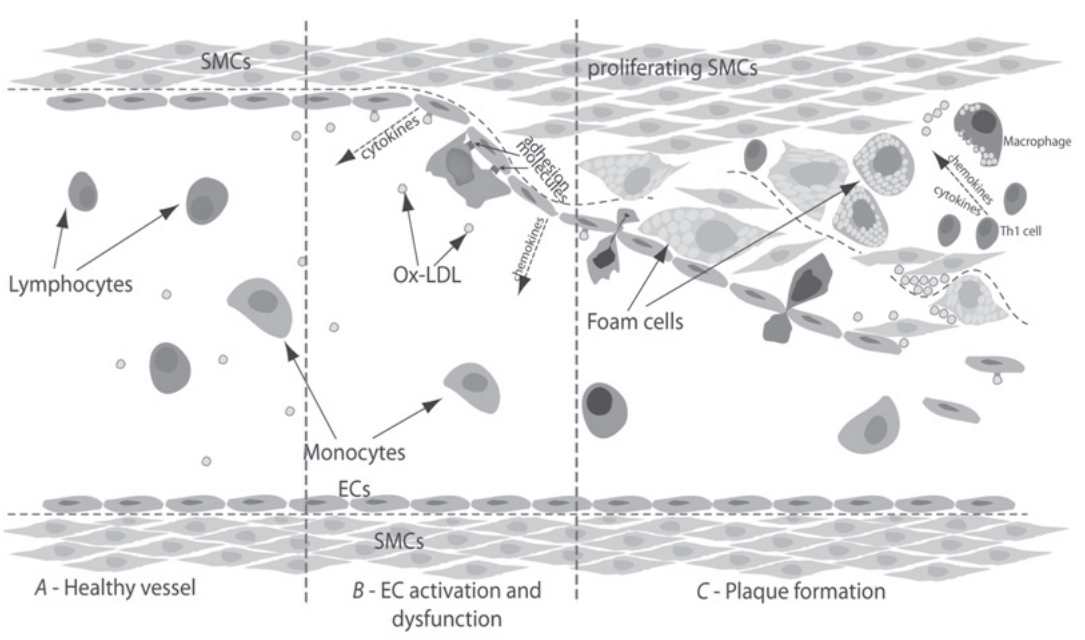

Figure 1. Formation of artheriosclerotic plaque

(A) A healthy vessel wall is built of a smooth muscle cell layer (SMCs), intima (dashed line) and an innermost layer of endothelial cells (ECS). (B) Activation of scavenger receptors by oxidized LDL particles (Ox-LDL) causes EC activation, which is characterized by secretion of cytokines and chemokines and presentation of adhesion molecules on the surface of ECs as well as increased permeability. Cytokines and chemokines attract lymphocytes and monocytes to the damaged site, adhesion molecules enable these cells to adhere to ECs and then to migrate through the EC layer. (C) Plaque formation involves detachment of ECs and proliferation of SMCs, and endocytosis of Ox-LDL by SMCs and macrophages, which causes these cells to become foam cells. Increased numbers and activation of Th1 cells are a general characteristic of atherosclerosis and involved in the promotion of lesion development and progression. As a consequence, in the progressive stages the lumen of the blood vessel becomes obstructed.

2002). Atherosclerosis is initiated when oxidized low density lipoproteins (ox-LDL) accumulate in the intima, causing oxidative stress and activating endothelial cells (EC). This leads to production of cell surface adhesion molecules, chemokines and inflammatory cytokines. These characteristics of EC dysfunction (Hack \& Zeerleder, 2001) form an initial step in atherosclerosis development. Subsequent recruitment and translocation of blood borne monocytes and naive lymphocytes from the circulation into the intima is followed by monocyte differentiation into macrophages and later on to foam cells. Lymphocytes have been implicated in the atherosclerotic process in a variety of ways. Subsets of $\mathrm{T}$ helper (Th) cells are important producers of pro-inflammatory cytokines; Th1 cells produce IFN $\gamma, \mathrm{TNF} \alpha$ and IL-12 and IL-18, all of which have been shown to promote atherogenesis (Robertson \& Hansson, 2006). Th2 cells secrete IL-4, IL-5, IL-10 and IL-13, and provide help for the recruitment of B-cells and their antibody production (Robertson \& Hansson, 2006). Increased numbers and activation of Th1 cells are a general characteristic of atherosclerosis and involved in the promotion of lesion development and progression. Th2 cytokines mostly antagonize pro-atherogenic Th1 effects and thereby should confer athero-protection. Finally, proliferation of smooth muscle cells (SMC) within the lesions is apparent, resulting in vessel occlusion. Excessive inflammatory and immune responses, communicated by these different cell types, are driven by inflammatory cytokines that promote associated tissue damage and contribute to local inflammation and vascular damage (Libby, 2002; Hansson et al., 2006). As such, in patients with CVD plasma levels of several pro-inflammatory factors (e.g. interleukin-6 (IL-6), tumor necrosis factor $\alpha(\mathrm{TNF} \alpha)$ and C-reactive protein $(\mathrm{CRP}))$ are recognized as markers of atherosclerosis.
RENAL DISEASE, INFLAMMATION AND CARDIOVASCULAR DISEASE

The well-known hallmarks of renal disease are formed by decreased filtration of blood components and neurohumoral dysregulation. Among the substances that accumulate are products that increase oxidative stress (AGEs, homocysteine, ox-LDL) (Himmelfarb et al., 2000; van Guldener et al., 2001; Schnackenberg, 2002; Galle et al., 2003; Locatelli et al., 2003). Indeed, increased reactive oxygen species (ROS) have been demonstrated in patients with CRF and ESRD (Schnackenberg, 2002; Locatelli et al., 2003). Increased sympathetic nervous system activity in CRF is well documented and is closely linked to hypertension and to increased activity of the renin-angiotensin system (RAS) that causes oxidative stress. Side effects of treatment may also result in oxidative stress, such as intravenous iron administration (Roob et al., 2000) and/or the passage of leukocytes through tubing and filters during hemodialysis (Menegatti et al., 2002).

Oxidative stress is a major initiator of an inflammatory response. This results in a shift towards the production (and activation) of pro-inflammatory cytokines, such as IL-1 $\beta$, IL-6 and IL- 8 and TNF $\alpha$ and IFNy (Saadeddin et al., 2002). Indeed, in CRF and ESRD, circulating levels of CRP (Wanner et al., 2002) IL-1 $\beta, T N F \alpha$ and IL- 6 , have been demonstrated to be predictors of endothelial dysfunction and atherosclerosis (Kato et al., 2002). Endothelial dysfunction is common in patients with moderate renal failure (Annuk et al., 2001) and also in ESRD patients undergoing hemodialysis (Miyazaki et al., 2000) or peritoneal dialysis (van Guldener et al., 1998), characterized by impaired endothelium-dependent vasodilation or increased soluble cell adhesion molecules (Bolton et al., 2001). In addition, renal disease at all stages is associated with activation of peripheral blood mononuclear cells (PBMC) (Sester et al., 2000; Tsirpanlis, 2007).

Patients with renal disease also display insensitivity to a diversity of humoral factors, including growth hormone (GH) (Lin et al., 1998), insulin (Roelfsema \& Clark, 2001), erythropoietin (EPO) (Stenvinkel \& Barany, 2002) and insulin growth factor 1 (IGF-1) (Lin et al., 1998). GH resistance leads to severe bone defects in children with chronic renal failure, which has also been related to a decreased sensitivity for IGF-1 (Lin et al., 1998; Roelfsema \& Clark, 2001). The anaemia that goes with renal failure is mainly due to a deficiency of EPO. Although decreased EPO levels are restored by administration of human recombinant EPO in severe CRF and ESRD, resistance to erythropoietin therapy is a common complication (Stenvinkel \& Barany, 2002). Insensitivity to several of these factors results in metabolic abnormalities and is associated with increased risk of CVD (Stenvinkel \& Barany, 2002; Mark et al., 2002; Wheatcroft et al., 


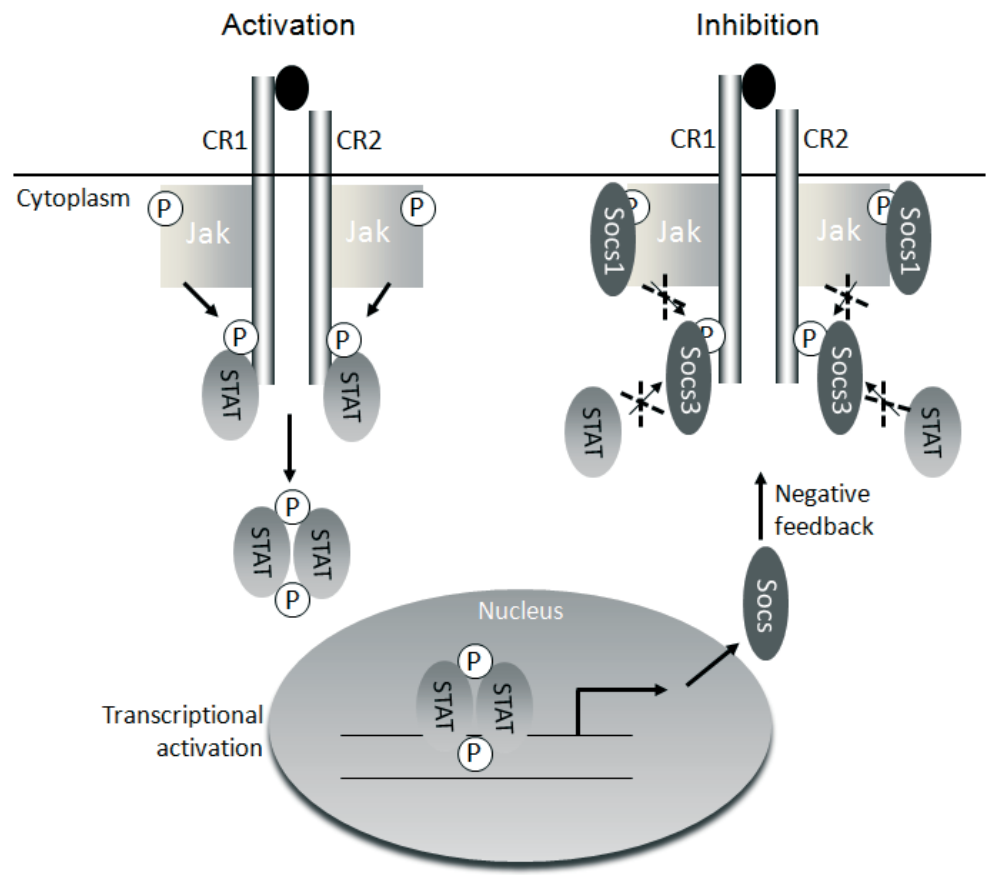

Figure 2. General paradigm of activation and SOCS-dependent inhibition of cytokine-mediated JAK/STAT signaling

Detailed description is given in the text. CR, cytokine receptor; JAK, Janus kinase; STAT, signal transducer and activator of transcription; $\mathrm{P}$, phosphorylated tyrosine residue; SOCS, suppressor of cytokine signaling.

2003). Insensitivity to humoral factors in patients with renal disease is also mediated by inflammation and inflammatory cytokines. These observations suggest a link between renal failure on the one hand and insensitivity to humoral factors, inflammation and atherosclerosis on the other. Thus, pathways capable of suppressing pro-inflammatory cytokine signaling hold the potential to limit life-threatening cardiovascular events in patients with renal disease.

Inflammation progresses by the action of pro-inflammatory cytokines, including IL- $1 \beta, \mathrm{TNF} \alpha, \mathrm{IFN} \gamma$, IL-6, IL-12, IL-18 and granulocyte-monocyte colony stimulating factor (GM-CSF). However, in most cases, the inflammatory response is resolved by the release of endogenous anti-inflammatory cytokines such as IL-4, IL-10, IL-13, IFN $\alpha$ and transforming growth factor (TGF $\beta)$. It has gained broad acceptance that the production of and cellular responsiveness to cytokines determines the balance between pro- and anti-inflammation (Dinarello, 1997). Nonetheless, the precise role that cytokines play in the mechanism of renal failure is still unclear.

Many inflammatory cytokines relay biological information to a wide variety of target cells by activating the JAK/STAT pathway (Levy \& Darnell, 2002; Levy \& Lee, 2002; Wesoly et al., 2007). In short, signaling from cytokine receptors is initiated by receptor oligomerization that is induced by cytokine binding, which brings associated Janus kinases (JAKs) (JAK13 , Tyk2) into close proximity and allows their cross-phosphorylation and activation (Fig. 2). The activated JAKs phosphorylate the receptor cytoplasmic domains at specific tyrosine residues, which create docking sites for the members of the signal transducer and activator of transcription (STATs) family: STAT1-6. Upon activation by phosphorylation, STAT molecules dimerize and translocate into the nucleus to activate gene transcription. Crucial immunoregulatory factors include the IL-2 family of cytokines (IL-2, IL-4, IL-7, IL-9, IL-15 and IL-21), that generally activate STAT5A and

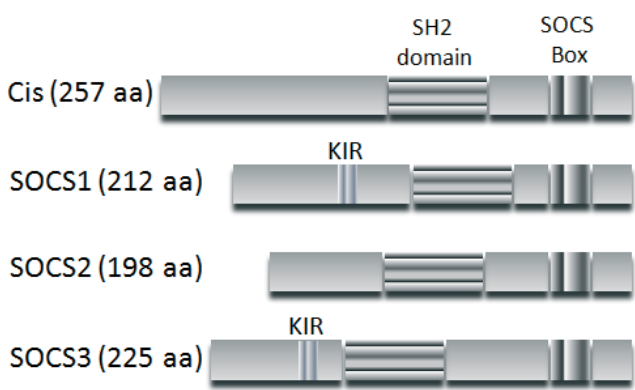

SOCS4 (436 aa)

SOCS5 (536aa)

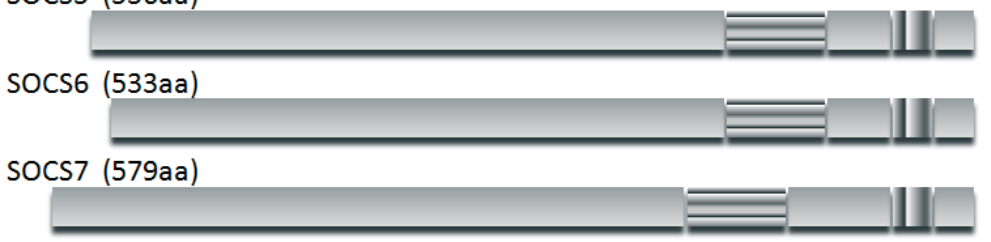

Figure 3. Schematic representation of the SOCS protein family and their conserved functional domains

Detailed description is given in the text. KIR, kinase inhibitory domain; SH2, Src-homology 2 domain; aa, amino acids.
STAT5B, sometimes STAT6 (activated by IL-4). Also IFN $\gamma$, activating mainly STAT1, but sometimes also STAT3, and members of the IL-6 family of cytokines IL-6, IL-10 and IL-11 using mostly STAT3 for downstream signaling, but sometimes STAT1. IL-12 acts upon STAT4.

The regulation of cellular responsiveness to cytokines determines cytokine activity and the balance between opposing cytokines. Control of the magnitude and duration of cytokine signaling is also essential to prevent pathology. Key regulators of cellular responses to cytokines are members of the suppressors of cytokine signaling protein family (SOCS; also known as cytokine-induced SH2-containing protein (CIS), JAK binding protein, or STAT-induced STAT inhibitor), which plays an important role in feedback inhibition and cytokine cross-regulation (Krebs \& Hilton, 2001; Alexander \& Hilton, 2004; Yoshimura et al., 2007; Dalpke et al., 2008). 
Table 1. Biological functions of SOCS proteins For references see main text

\begin{tabular}{|c|c|c|c|}
\hline Gene & Knockout phenotype & Transgenic phenotype & Main affected cytokines \\
\hline CIS & $\begin{array}{l}\text { (?) Increased hematopoiesis } \\
\text { disturbed lactation }\end{array}$ & Reduced weight, & $\begin{array}{l}\text { STAT5 signaling } \\
\text { (EPO, IL-2, IL-3) }\end{array}$ \\
\hline SOCS1 & $\begin{array}{l}\text { Multiorgan inflammation, } \\
\text { neonatal lethality, } \\
\text { lymphocyte apoptosis, } \\
\text { hematopoietic infiltrations }\end{array}$ & $\begin{array}{l}\text { Disturbed T-lymphocyte development, } \\
\text { spontaneous T-cell activation }\end{array}$ & $\begin{array}{l}\text { IFN } \gamma, \text { IFNa, IL-4, } \\
\text { IL-12 }\end{array}$ \\
\hline SOCS2 & Gigantism & Gigantism & GH, IGF-1 \\
\hline SOCS3 & $\begin{array}{l}\text { Embryonic lethality, } \\
\text { Placenta defects, } \\
\text { Disturbed erythropoiesis }\end{array}$ & $\begin{array}{l}\text { Embryonic lethality, } \\
\text { increased Th2 differentiation, }\end{array}$ & $\begin{array}{l}\text { gp130, IL-2, IL-6, } \\
\text { G-CSF, leptin, } \\
\text { EPO }\end{array}$ \\
\hline SOCS4 & $(?)$ & $(?)$ & $(?)$ \\
\hline SOCS5 & $\begin{array}{l}\text { (?) No obvious phenotype } \\
\text { (redundancy with SOCS4?) }\end{array}$ & Disturbed Th2 differentiation & IL-4, EGF \\
\hline SOCS6 & $\begin{array}{l}\text { Mild growth retardation } \\
\text { (redundancy with SOCS7?) }\end{array}$ & $\begin{array}{l}\text { Improved glucose and } \\
\text { insulin tolerance }\end{array}$ & Insulin (?) \\
\hline SOCS7 & $\begin{array}{l}\text { Hydrocephalus, } \\
50 \% \text { mortality, } \\
\text { Hyperinsulinemia }\end{array}$ & $(?)$ & Insulin \\
\hline
\end{tabular}

\section{MODULATION OF CYTOKINE SIGNALING BY SOCS}

SOCS protein expression is rapidly induced by many cytokines, including those that activate the JAK/STAT pathway. SOCS expression is tightly regulated at the transcriptional level. SOCS mRNAs are induced by cytokines, and the corresponding SOCS proteins can extinguish the signaling pathways that stimulate their production. SOCS proteins therefore act in part of a classical negative feedback loop (Alexander \& Hilton, 2004; Yoshimura et al., 2007). Individual SOCS proteins are capable of inhibiting multiple cytokines, but it is not clear how the specificity of inhibition by SOCS is regulated. SOCS are also induced by various other stimuli, such as angiotensin II (AngII), lipopolysaccharide (LPS), growth factors (epidermal growth factor (EGF), platelet-derived growth factor (PDGF)), isoproterenol, statins and cyclic AMP (cAMP), and SOCS1 expression in immature thymocytes is developmentally regulated in the absence

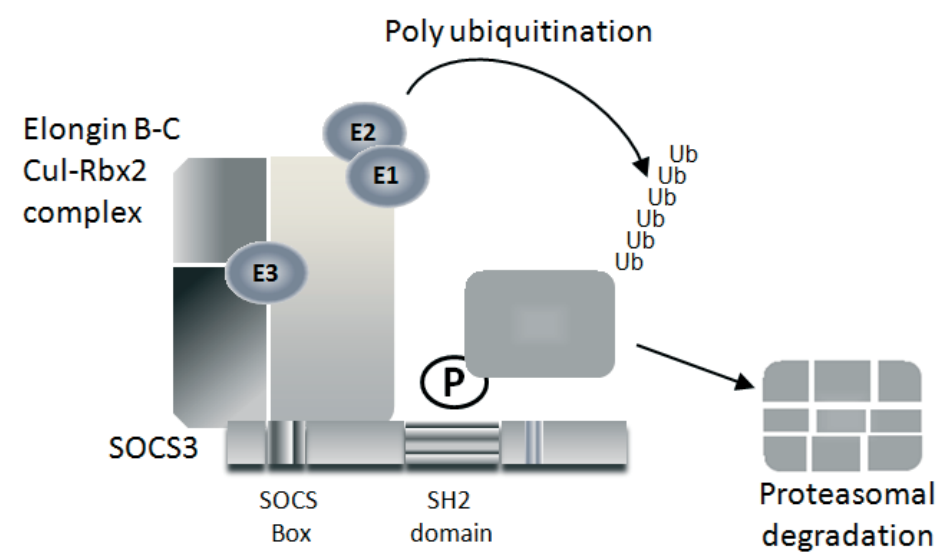

Figure 4. Proteasomal degradation of SOCS-targeted proteins

An E3 ubiquitin-ligase complex bound to the SOCS box motif, ubiquitinates the associated proteins targeting them for proteasomal degradation. Detailed description is given in the text. SOCS, suppressor of cytokine signaling; SH2, Src-homology 2 domain; Ub, ubiquitin; Cul, Cullin; E1, ubiquitin-activating enzyme; E2, ubiquitin-conjugating enzyme; E3, ubiquitin ligase complex. of cytokine signaling. Therefore, SOCS proteins are involved in a wide range of biological processes.

The family of SOCS proteins comprises 8 members: CIS, which was the first identified member (Yoshimura et al., 1995), and SOCS1-SOCS7 (Fig. 3). All members exhibit a similar structure and contain a central Src homology 2 (SH2) domain and a conserved C-terminal 40-residue region termed the SOCS box (Krebs \& Hilton, 2001; Yoshimura et al., 2007). SOCS1 and SOCS3 also contain a conserved 12-residue sequence - the kinase inhibitory region (KIR) (Yasukawa et al., 1999). The N-terminal regions have no recognizable motifs (except SOCS7 which contains a possible nuclear localization signal and multiple proline-rich regions).

SOCS proteins control the magnitude and duration of JAK/STAT signaling through at least three possible mechanisms, including receptor interaction, direct JAK inhibition, and targeting receptor complex, and other signaling proteins for proteasomal degradation (Fig. 2 and Fig. 4). The SH2 domain determines in this aspect the target of each SOCS and CIS protein. For example, CIS, SOCS2 and SOCS3 bind to phosphorylated tyrosine residues on cytokine receptors to compete for binding sites that are used to recruit and activate STATs. The KIR domain of SOCS1 and SOCS3 allows them to inhibit JAK tyrosine kinase activity. As such, the KIR domain is proposed to function as a pseudosubstrate and prevent STATs from gaining access to the kinase (Figs. 2 and 3). SOCS1 binds directly to the activation loop of JAKs through its $\mathrm{SH} 2$ domain, the $\mathrm{SH} 2$ domain of SOCS3 first binds the cytokine receptor before inhibiting JAK through its KIR (Figs. 2 and 3).

The SOCS box serves recruitment of the ubiquitin-transferase system. As such, the SOCS box consists of three $\alpha$-helices bound to an E3 ubiquitin ligase complex that together with an E1 ubiquitinactivating enzyme, and an E2 ubiquitinconjugating enzyme results in the poly- 
ubiquitination and proteasomal degradation of SOCS binding partners. The active ligase is formed by SOCS interacting with Elongins B and C, Cullin-5 or Cullin-2, and Rbx-1 (Kamura et al., 1998). Thus, SOCS proteins function as potential E3 ubiquitin ligases and mediate the degradation of proteins associated with their SH2domains (Fig. 4).

\section{BIOLOGICAL FUNCTIONS OF SOCS PROTEINS}

From in vitro studies it could be concluded that various SOCS members are able to inhibit a variety of different as well as overlapping cytokines. In vivo data, however, argue for their more restricted and specific roles (Table 1). Of interest in this respect is that homology in protein identities is present in pair-wise clusters between SOCS1/SOCS3, CIS1/SOCS2, SOCS4/SOCS5, and SOCS6/SOCS7 (Dalpke et al., 2008).

CIS serves as a negative regulator of EPO, IL-2, IL-3, prolactin and GH action (Yoshimura et al., 1995) by inhibiting STAT5. Transgenic mice overexpressing CIS1 are strikingly similar to STAT5 knockout mice, displaying growth retardation, defects in mammary gland development, and severe defects in natural killer cell, natural killer $\mathrm{T}$ cell, and $\mathrm{T}$-cell development; in addition, their helper $\mathrm{T}$ cells are biased toward Th2 differentiation (Matsumoto et al., 1999). On the other hand, CIS1-/- mice have no phenotype (Marine et al., 1999), although T-cells and hematopoietic cells of these mice are hyper-responsive to EPO (Sasaki et al., 2000).

SOCS1 emerged as a potential negative regulator of many cytokines, including IL-2, IL-4, IL-6, IL-12. In addition, SOCS1 interacts directly with the type I IFN receptor and the IFN $\gamma$ receptor, implicating a very efficient suppressive effect of SOCS1 on IFN signaling. Moreover, SOCS1 is highly induced by LPS, implying that SOCS1 not only inhibits the JAK/STAT pathway, but also the toll-like receptor (TLR)-NF- $\kappa \mathrm{B}$ pathway (Mansell et al., 2006). SOCS1--- mice are normal at birth, but die within 3 weeks of rapidly developed pathological manifestations such as severe lymphopenia, activation of peripheral $\mathrm{T}$ cells, fatty degeneration and necrosis of the liver, and macrophage infiltration of major organs (Naka et al., 1998; Starr et al., 1998). Defects in SOCS1-/- mice appear as a result of uncontrolled IFN $\gamma$ signaling (Starr et al., 1998). In fact the specific role of SOCS-1 in inhibition of IFN $\gamma$-STAT1signaling has been confirmed in other studies as well (Yasukawa et al., 1999). Moreover, data from SOCS1I- mice suggest that SOCS1 could potentially modulate cell responses to other cytokines as well. For instance, SOCS1-1- mice demonstrate enhanced proliferation of thymocytes and prolonged duration of STAT6 activation upon IL-4 treatment (Naka et al., 1998), indicating a state of hyper-responsiveness in hematopoetic cells to IL-4 (Alexander et al., 1999b; Losman et al., 1999). Furthermore, SOCS1 inhibits IL-6-induced macrophage differentiation (Novak et al., 1999). Even more interesting data regarding the anti-inflammatory effects of SOCS1 were obtained from the SOCS1 transgenic mice that specifically over-express SOCS1 in T-cells. In this mouse model the activation of STATs in response to stimulation with IFN $\gamma$, IL-4, IL-6 and IL-7 is significantly reduced. This suggests that SOCS1 can attenuate signaling from a wide range of cytokines.

SOCS2 has been shown to be a negative regulator of GH-STAT5 and IGF-1 (Greenhalgh et al., 2002; 2005).
SOCS2-deficient mice develop gigantism, supporting the importance of SOCS2 in the regulation of growth. Interestingly, transgenic SOCS2 mice also have gigantism (Greenhalgh et al., 2002), illustrating the complexity of the role of SOCS2 action in vivo.

SOCS3 mainly binds to gp130-related cytokine receptors (Nicholson et al., 2000) as a central regulator of for example IL-6 signaling, but also has been shown to interact with receptors for leptin, EPO and granulocyte colony-stimulating factor (G-CSF) (Takahashi et al., 2003; Kimura et al., 2004). Moreover, SOCS3 suppresses LPSsensitivity in mice and macrophages probably through inhibition of the JAK/STAT-independent MyD88-dependent pathway (Nakagawa et al., 2002). SOCS3 knockout mice die during embryonic development either by dysregulated fetal liver erythropoiesis or defects of placenta functions (Marine et al., 1999; Roberts et al., 2001). Conditional KO mice studies of SOCS3 in macrophages have proven that SOCS3 is an important negative regulator of IL-6 (Croker et al., 2003; Lang et al., 2003; Yasukawa et al., 2003). By use of other conditional KO strategies, further roles of SOCS3 in hematopoiesis and the endocrine system have been substantiated for G-CSF, leptin and EPO (Croker et al., 2004; Mori et al., 2004).

Within the SOCS subfamily, SOCS4, SOCS5, SOCS6 and SOCS7 remain poorly understood. Little is known about SOCS4 function in cytokine signaling, except that SOCS4 levels are upregulated on EGF stimulation ( $\mathrm{Ka}$ rio et al., 2005).

SOCS5 can bind to the IL-4R and suppress STAT6 phosphorylation in Th1 cells. In addition, SOCS5 protein is selectively expressed in Th1 cells, and SOCS5 transgenic mice have disrupted Th2-cell responses and attenuated IL-4 signaling (Seki et al., 2002). SOCS5 $5^{-1-}$ mice, however, have normal T-cell development (Brender et al., 2004).

In vitro, SOCS6 interacts with the insulin receptor, insulin receptor substrate (IRS)-4, and inhibits IRS-1 phosphorylation (Krebs et al., 2002). Over-expressed SOCS6 can inhibit insulin signaling. Although SOCS6 transgenic mice display improved glucose and insulin tolerance, SOCS6-/- mice do not appear to be more insulin-responsive than wild-type mice. Except for reduced weight by $8 \%$ to $10 \%$, these mice seem otherwise normal (Krebs et al., 2002). Thus, in vivo functions of SOCS4-6 are not well defined.

SOCS7-/- mice similarly show mild growth retardation. In addition, however, about $50 \%$ of the mice develop hydrocephalus and suffer neonatal death (Krebs et al., 2004). SOCS7 can interact with STAT3 and STAT5 after prolactin or leptin-induced stimulation (Martens et al., 2005). SOCS7 mRNA levels are induced by insulin stimulation. In vitro, SOCS7 interacts with the insulin receptor and IRS-1 (Banks et al., 2005). SOCS7 KO mice are hypersensitive to insulin, suggesting an essential role for SOCS7 in the regulation of insulin signaling in vivo.

In conclusion, cytokines can induce negative feedback in their own signaling pathways as well as inhibit action of other cytokines through cross-inhibition, via SOCS proteins. In this way SOCS proteins are able to dampen the response to both harmful and to beneficial signals. Furthermore, beyond this classic point of view, increased SOCS expression reflects the activation of intracellular inflammatory pathways that could indicate whether cells experience inflammation. The latter suggests that SOCS expression could be used as a new intracellular marker related to inflammation and inflammatory-related diseases. 
Table 2. SOCS1 and SOCS3 in inflammatory diseases

For references see main text

\begin{tabular}{|c|c|c|}
\hline Disease & SOCS expression & $\begin{array}{l}\text { SOCS therapy in experimental } \\
\text { model }\end{array}$ \\
\hline Rheumatoid Arthritis & Increased SOCS3 mRNA in synovial tissue & Overexpression-Protective \\
\hline Asthma & Increased SOCS3 mRNA and protein in Th2 lymphocytes with severity & Overexpression-Damaging \\
\hline Atherosclerosis & Increased SOCS1 and SOCS3 mRNA in lesional SMC and macrophages & Overexpression-Protective \\
\hline Ulcerative Colitis & Increased SOCS3 mRNA and protein in colon tissue & $\begin{array}{l}\text { Overexpression-Protective } \\
\text { Deletion-Damaging }\end{array}$ \\
\hline Crohn Disease & Increased SOCS3 mRNA and protein in mucosal sample & $\begin{array}{l}\text { Overexpression-Protective } \\
\text { Mutation-Damaging }\end{array}$ \\
\hline Dermatitis & $\begin{array}{l}\text { Increased SOCS1, SOCS2, and SOCS3 protein in keratinocytes and infil- } \\
\text { trating leukocytes }\end{array}$ & nd \\
\hline \multicolumn{3}{|l|}{ Renal Failure } \\
\hline CRF & Increased SOCS3 mRNA in monocytes and SOCS1 in lymphocytes & nd \\
\hline ESRD & Increased SOCS1 in monocytes and SOCS1 and CIS in lymphocytes & nd \\
\hline
\end{tabular}

\section{SOCS AS A BIOMARKER OF CARDIOVASCULAR DISEASE IN CRF AND ESRD}

Accumulating evidence shows that dysregulation of cytokine signaling by differential SOCS expression is involved in the pathogenesis of various inflammatory, immune and infectious diseases (see Table 2). Indeed, evidence is emerging for the involvement of especially SOCS1 and SOCS3 in inflammatory diseases, such as rheumatoid arthritis, and inflammatory bowel disease (IBD) as well as dermatitis. In general, SOCS1 and SOCS3 expression inhibits inflammatory diseases (Chen et al., 2004; Fujimoto et al., 2004). SOCS3 expression is increased in the colon of mice in an experimental model of colitis, and in intestinal T cells from Crohn's disease patients (Suzuki et al., 2001; Niemand et al., 2003). Inhibition of SOCS3 activity, using a dominant-negative transgene, induced hyperactivation of STAT3, and increased the severity of colitis in mice (Niemand et al., 2003). In contrast, in asthma the degree of SOCS3 expression correlates with the severity of the disease (Tang \& Raines, 2005), indicating a dual role of SOCS3 in inhibition as well as promotion of inflammatory diseases.

SOCS proteins have also been implicated as important modulators of cell activation during renal inflammation. For example, in experimental models of immune complex glomerulonephritis, the renal expression of SOCS3 significantly increased, in parallel with proteinuria and renal lesions, and the proteins were localized in glomeruli and tubulointerstitium (Gomez-Guerrero et al., 2004). On the other hand, SOCS2 was found to be upregulated in skeletal muscle of ESRD patients during hemodialysis (Raj et al., 2005). Others provided evidence to suggest that SOCS proteins may act as negative regulators of AngII signaling in renal cells and implicated SOCS as important modulators of renal damage (Hernandez-Vargas et al., 2005).

Recently, we demonstrated for the first time increased expression of SOCS3 in monocytes and of SOCS1 in lymphocytes of CRF patients, accompanied by increased plasma levels of the inflammatory cytokines IL-6 and TNF $\alpha$ (Rastmanesh et al., 2008). Interestingly, increased monocyte SOCS3 significantly correlated with progressive loss of renal function, measured by estimated GFR and urea. Moreover, lymphocyte SOCS1 correlated with other known markers and risk factors of CVD such as $\mathrm{TNF} \alpha$, systolic blood pressure (SBP) and pulse wave velocity (PWV), of which the latter have been related to arterial stiffness (Briet et al., 2006) and to outcome in renal disease (Blacher et al., 1999).

Our additional study in ESRD patients (Rastmanesh et al., 2009) revealed increased monocyte SOCS1 and lymphocyte SOCS1 and CIS1, accompanied by increased plasma levels of IL-6, TNF $\alpha$, and CRP. Interestingly, monocyte SOCS1 correlated with plasma IL-6 levels, linking monocyte SOCS1 to enhanced activity of this known marker of inflammation and cardiovascular disease. CIS1 was significantly increased in lymphocytes of non-dialysis and peritoneal dialysis patients but not in hemodialysis, potentially pointing to different inflammatory conditions or cell responsiveness in hemodialysis patients (Dhondt et al., 2000) in relation to the hemodialysis procedure (Martin-Malo et al., 2000). Indeed CRP was only significantly increased in hemodialysis patients, but not in the other subgroups. We also found a significant correlation between lymphocyte CIS1 and TNF $\alpha$, again confirming a link between systemic inflammation and SOCS expression in mononuclear cells in ESRD.

Together, these data are in agreement with other inflammatory diseases, and reveal that SOCS expression levels are profoundly altered in kidney disease, and the profile of SOCS expression is dependent on both the cell type as well as severity of the disease and dialysis modality. More important, we propose to suggest that SOCS could be a new intracellular marker of inflammation and CVD in renal patients, which has to be confirmed in larger CRF and ESRD cohorts.

\section{SOCS1 AND SOCS3 IN ATHEROSCLEROSIS}

Increased SOCS expression has recently also been recognized in atherosclerosis. For example, SOCS1 and SOCS3 were increased in aortic lesions from $\mathrm{ApoE}^{-/-}$mice (Tang et al., 2005) and both co-localized with Mac-2 positive lesion macrophages. Recently, Yamamoto and colleagues revealed that the absence of SOCS3 in macrophages of ApoE $^{-/-}$mice decreases atherosclerosis (Yamamoto et al., 2007), indicating a causal link between SOCS3 and atherosclerosis. In addition, in human plaques high expression of both SOCS1 and SOCS3 was revealed in VSMCs and macrophages in the inflammatory region of the shoulders, when compared to the fibrous area (Ortiz-Munoz et al., 2009). In vivo, antisense oligodeoxynucleotides targeting SOCS3 exacerbated the atherosclerotic process in $\mathrm{ApoE}^{-/-}$mice by increasing the size, leuko- 
cyte content, and chemokine expression in the lesions (Ortiz-Munoz et al., 2009). Finally, Taleb et al. (2009) showed that loss of SOCS3 in T-cells increases both IL17 and IL-10 production, induces an anti-inflammatory macrophage phenotype, and leads to unexpected IL-17dependent reduction in lesion development and vascular inflammation.

SOCS1 and SOCS3 are important modulators of lymphocyte development, differentiation, cytokine production and activation (Alexander et al., 1999a; Li et al., 2000; Zhang et al., 2001). SOCS1 is specifically expressed in Th1 cells and SOCS3 in Th2. Monocyte survival, activation and differentiation depend on the action of different inflammatory cytokines, including IFN $\gamma$ and IL-6, and the action of SOCS1 and SOCS3. SOCS expression can also be increased in cells from the vasculature. For example, in cultured VSMCs and ECs SOCS1 and SOCS3 were shown to be transiently induced by proinflammatory cytokines, proatherogenic lipoproteins, and immune molecules (Ortiz-Munoz et al., 2009). Furthermore, over-expression of SOCS in these cell models suppressed STAT activation and reduced inflammatory gene expression and cell growth, whereas SOCS knockdown increased these cell responses. Our laboratory provides novel evidence to suggest that in ECs and VSMCs in vitro increased SOCS3 expression, induced by pro-inflammatory factors like IFN $\gamma$ and LPS, specifically inhibits the anti-inflammatory and proliferative effects of IL-6 through STAT3 and shifts IL-6 signaling in favor of a pro-inflammatory phenotype (Bluyssen et al., 2010). This could represent a novel mechanism involved in endothelial dysfunction and in the initiation and progression of atherosclerosis.

Thus, SOCS1 and SOCS3 expressed in atherosclerotic lesions are key regulators of vascular and immune cell responses, strongly implying that manipulation of these endogenous inhibitors might be of interest in the treatment of atherosclerosis.

\section{SOCS1 AND SOCS3 AND ATHEROGENIC PROPERTIES IN RENAL FAILURE RELATED CVD}

The increased SOCS1 and SOCS3 expression in PBMCs of CRF and ESRD patients could therefore probably reflect initiation or development of cardiovascular disease.

In case of SOCS3, it has recently been demonstrated that it predominantly plays a negative regulatory role of STAT3 activation and in biologic responses to IL-6 (Croker et al., 2003; Lang et al., 2003; Yasukawa et al., 2003). Moreover, in SOCS3 ${ }^{-/-}$cells IL-6 acts like IL10 and has anti-inflammatory effect by inhibiting LPSinduced production of TNF $\alpha$ and IL-12. This anti-inflammatory effect of IL-6 is mediated by STAT3 activation, which is prolonged in SOCS3--- macrophages. According to these findings, it could be suggested that SOCS3 has pro-inflammatory effects in macrophages, which is related to inhibition of STAT3-dependent antiinflammatory effects of IL-6. It is tempting to speculate that increased expression of SOCS3 in monocytes of CRF patients causes (partial) resistance to IL-6 (induced STAT3 activation) or other cytokines. SOCS3 expression in monocytes seems to have pro-atherogenic properties (Yamamoto, 2007; Ortiz-Munoz et al., 2009). Therefore, increased monocyte SOCS3 in chronic kidney disease patients could be related to higher prevalence of cardiovascular disease. In fact, the chance of cardiovascular death in chronic kidney disease patients is 5-10 times more than the chance of reaching the end stage stadium (Collins et al., 2003).

With respect to SOCS1, in vivo and in vitro studies indicate a specific role for this protein in inhibition of IFN $\gamma$ signaling, which has a central role in atherosclerosis (Leon \& Zuckerman, 2005). Therefore, increased SOCS1 in monocytes of ESRD patients, could delay monocyte responses to pro-inflammatory cytokines and delay atherosclerosis. In fact, SOCS1 inhibits IL-6-induced macrophage differentiation (Novak et al., 1999) and IFN $\gamma$-induced CD40 production that is involved in initiation of atherosclerosis (Wesemann et al., 2002). Previous studies, however, indicate an increased number of activated monocytes with a pro-inflammatory phenotype in ESRD (Brauner et al., 1998; Heine et al., 2008), which might suggest that increased monocyte SOCS1 is insufficient to dampen increased inflammatory pressure on monocytes. A similar phenomenon has been shown for example in synoviocytes of rheumatoid arthritis patients, which are hyper-responsive to IL-6 because of inadequate levels of SOCS3 (Shouda et al., 2001). Whether increased SOCS1 in monocytes of ESRD patients is in proportion with increased pro-inflammatory cytokines and whether it could efficiently dampen pro-inflammatory signals remains unclear.

Since SOCS1 expression in Th1 cells specifically inhibits the growth inhibitory effects of IFN $\gamma$ on these cells, but not on Th2 cells (Alexander et al., 1999a), it is possible that increased lymphocyte SOCS1 in CRF and ESRD skews the immune response to the Th1 type in these patients, which is in agreement with previous studies (Egwuagu et al., 2002), and the promotion of atherogenesis. On the other hand, insufficient SOCS1 expression in lymphocytes causes hyper-responsiveness of lymphocytes to different inflammatory cytokines (Fujimoto et al., 2004). Moreover, the absence of SOCS1 results in increased accumulation of macrophages and activated $\mathrm{T}$ cells and increased levels of IFN $\gamma$ and other cytokines, and is associated with greater tissue damage in arthritis (Egan et al., 2003) which could also promote atherosclerosis.

\section{SOCS IN LOCAL AND SYSTEMIC COMPLICATIONS OF RENAL FAILURE}

As implicated above, inflammation is induced in CRF and ESRD by overproduction of pro-inflammatory cytokines, such as TNF $\alpha$ and IL- 6 by chronically active mononuclear cells or decreased clearance of inflammatory cytokines. Several inflammatory cytokines, including IL-6, IFN $\gamma$ and $\mathrm{TNF} \alpha$ can induce SOCS proteins in vitro and in vivo. Over-expression of these cytokines could induce a state of resistance to GH and EPO. Both factors have protective effects, since $\mathrm{GH}$ resistance causes endothelial dysfunction and EPO therapy could limit cytokine production by activated mononuclear cells. Recently it was shown that dysregulation of JAK/STAT signaling, by increased levels of the intracellular proteins SOCS2 and SOCS3, contribute to the GH resistance in rats with experimental CRF, leading to decreased IGF1 levels (Schaefer et al., 2001; Wang et al., 2002). Similarly, CIS1 and SOCS3 might be involved in EPO resistance (see above). Impaired JAK/STAT signaling by increased SOCS expression has also been correlated with other systemic implications, including immune deficiencies (Losman et al., 1999; Banerjee et al., 2002), insulin 


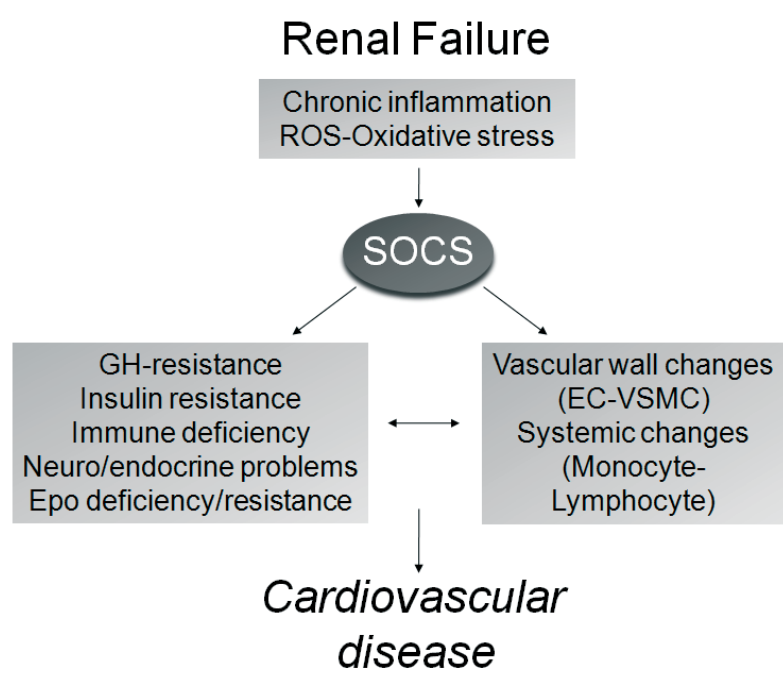

Figure 5. Hypothetical convergence of SOCS in renal failure related cardiovascular disease

Detailed description is given in the text. ROS, reactive oxygen species; SOCS, suppressor of cytokine signaling; EC, endothelial cells; VSMC, vascular smooth muscle cell; EPO, erythropoietin; GH, growth hormone.

resistance (Grimble, 2002; Rui et al., 2002), and neuroendocrine (LIF signaling) problems (Auernhammer \& Melmed, 2001; Chesnokova \& Melmed, 2002), which are also associated with renal disease.

On the other hand, insufficient induction of SOCS could allow harmful signals (that pass through JAK/ STAT) to act without being interrupted that results in further inflammation. For instance, IFN $\gamma$, that has obvious pro-inflammatory and pro-atherogenic effects, is specifically modulated by SOCS1. The absence or insufficient induction of SOCS1 will result in prolonged and increased activation of IFN $\gamma$-induced STAT1 activation. That will result in increased macrophage activation, increased production of adhesion molecules, and increased production of cytokines by both mononuclear cells and endothelial cells. Therefore, insufficient SOCS expression is also involved in dysregulation of JAK/STAT pathway and consequently in its detrimental effects.

Together this could implicate that systemic inflammation in CRF and ESRD results in JAK-STAT impairment and increased action of damaging factors and inhibited transmission of beneficial factors such as EPO, insulin and GH because of increased SOCS expression (Fig. 5). As such, increased SOCS expression in mononuclear as well as vascular cells could possibly indicate the state of cell responsiveness to $\mathrm{GH}$ and Epo therapy. In addition, increased SOCS expression could be a reflection and/or mediator of vascular wall and circulating cellular changes, which are responsible for the increased risk of CVD and contribute to endothelial dysfunction and the progression of atherosclerosis in renal patients. Our finding that SOCS indeed are up regulated in circulating leukocytes of patients with CRF and ESRD provides the first clue that this disturbance actually exists in these patients.

\section{CONCLUSION}

SOCS1 and SOCS3 are frequently increased in inflammatory diseases (Wong et al., 2006). A recent study has demonstrated increased monocytes SOCS3 and lym- phocyte SOCS1 expression in rheumatoid arthritis patients (Isomaki et al., 2007) and patients with renal failure (Rastmanesh, 2008; 2009). SOCS1 and SOCS3 are also critical modulators of inflammatory processes within different cell types of the atherosclerotic vascular wall. The question remains how changes in SOCS1 and SOCS3 expression in renal failure affect monocyte and lymphocyte function in relation to immune responses and CVD and whether these changes also occur in ECs and VSMCs in the vascular wall. Characterizing the role of SOCS1 and SOCS3 in more detail in the development of CVD in CRF and ESRD patients may well provide new therapeutic targets for CVD. Finally, the value of monocyte and lymphocyte SOCS1 and SOCS3 as a new marker of CVD in chronic kidney disease needs to be confirmed in larger CRF and ESRD cohorts. Once confirmed, SOCS could become a marker of subclinical CVD in renal patients without clinical manifestations of CVD. Systemic or local manipulation of these endogenous anti-inflammatory proteins might be a therapeutic strategy for treating cardiovascular diseases.

\section{Acknowledgements}

This publication was supported by Cordis FP6, Marie Curie Transfer of Knowledge project: MTKDCT-2004-517068; Polish Foundation of Science: J.W. is a Laureate of the "FOCUS" program. Polish Ministry of Science and Higher Education: N N401 004035, N N302 331233.

\section{REFERENCES}

Alexander WS, Hilton DJ (2004) The role of suppressors of cytokine signaling (SOCS) proteins in regulation of the immune response. Annu Rev Immunol 22: 503-529.

Alexander WS, Starr R, Fenner JE, Scott CL, Handman E, Sprigg NS, Corbin JE, Cornish AL, Darwiche R, Owczarek CM, Kay TW, Nicola NA, Hertzog PJ, Metcalf D, Hilton DJ (1999a) SOCS1 is a critical inhibitor of interferon gamma signaling and prevents the potentially fatal neonatal actions of this cytokine. Cell 98: 597-608.

Alexander WS, Starr R, Metcalf D, Nicholson SE, Farley A, Elefanty AG, Brysha M, Kile BT, Richardson R, Baca M, Zhang JG, Willson TA, Viney EM, Sprigg NS, Rakar S, Corbin J, Mifsud S, DiRago L, Cary D, Nicola NA, Hilton DJ (1999b) Suppressors of cytokine signaling (SOCS): negative regulators of signal transduction. I Leukoc Biol 66: 588-592.

Annuk M, Lind L, Linde T, Fellstrom B (2001) Impaired endotheliumdependent vasodilatation in renal failure in humans. Nephrol Dial Transplant 16: 302-306.

Auernhammer CJ, Melmed S (2001) The central role of SOCS-3 in integrating the neuro-immunoendocrine interface. J Clin Invest 108: 1735-1740

Banerjee A, Banks AS, Nawijn MC, Chen XP, Rothman PB (2002) Cutting edge: suppressor of cytokine signaling 3 inhibits activation of NFATp. J Immunol 168: 4277-4281.

Banks AS, Li J, McKeag L, Hribal ML, Kashiwada M, Accili D, Rothman PB (2005) Deletion of SOCS7 leads to enhanced insulin action and enlarged islets of Langerhans. J Clin Invest 115: 2462-2471.

Blacher J, Guerin AP, Pannier B, Marchais SJ, Safar ME, London GM (1999) Impact of aortic stiffness on survival in end-stage renal disease. Circulation 99: 2434-2439.

Bluyssen HA, Rastmanesh MM, Tilburgs C, Jie KE, Wesseling S, Goumans MJ, Boer P, Joles JA, Braam B (2010) IFN $\gamma$-dependent SOCS3 expression inhibits IL-6 induced STAT3 phosphorylation and differentially affects IL- 6 mediated transcriptional responses in endothelial cells. Am J Physiol Cell Physiol 299: C354-C362.

Bolton CH, Downs LG, Victory JG, Dwight JF, Tomson CR, Mackness MI, Pinkney JH (2001) Endothelial dysfunction in chronic renal failure: roles of lipoprotein oxidation and pro-inflammatory cytokines. Nephrol Dial Transplant 16: 1189-1197.

Brauner A, Lu Y, Hallden G, Hylander B, Lundahl J (1998) Difference in the blood monocyte phenotype between uremic patients and healthy controls: its relation to monocyte differentiation into macrophages in the peritoneal cavity. Inflammation 22: 55-66.

Brender C, Columbus R, Metcalf D, Handman E, Starr R, Huntington N, Tarlinton D, Odum N, Nicholson SE, Nicola NA, Hilton DJ, 
Alexander WS (2004) SOCS5 is expressed in primary B and T lymphoid cells but is dispensable for lymphocyte production and function. Mol Cell Biol 24: 6094-6103.

Briet M, Bozec E, Laurent S, Fassot C, London GM, Jacquot C, Froissart M, Houillier P, Boutouyrie P (2006) Arterial stiffness and enlargement in mild-to-moderate chronic kidney disease. Kidney Int 69: $350-357$.

Chan CM (2005) Hyperlipidaemia in chronic kidney disease. Ann Acad Med Singapore 34: 31-35.

Chen Y, Chong MM, Darwiche R, Thomas HE, Kay TW (2004) Severe pancreatitis with exocrine destruction and increased islet neogenesis in mice with suppressor of cytokine signaling-1 deficiency. Am J Pathol 165: 913-921.

Chesnokova V, Melmed S (2002) Minireview: Neuro-immuno-endocrine modulation of the hypothalamic-pituitary-adrenal (HPA) axis by gp130 signaling molecules. Endocrinology 143: 1571-1574.

Collins AJ, Li S, Gilbertson DT, Liu J, Chen SC, Herzog CA (2003) Chronic kidney disease and cardiovascular disease in the Medicare population. Kidney Int Suppl S24-31.

Croker BA, Krebs DL, Zhang JG, Wormald S, Willson TA, Stanley EG, Robb L, Greenhalgh CJ, Forster I, Clausen BE, Nicola NA, Metcalf D, Hilton DJ, Roberts AW, Alexander WS (2003) SOCS3 negatively regulates IL-6 signaling in vivo. Nat Immunol 4: 540-545.

Croker BA, Metcalf D, Robb L, Wei W, Mifsud S, DiRago L, Cluse LA, Sutherland KD, Hartley L, Williams E, Zhang JG, Hilton DJ, Nicola NA, Alexander WS, Roberts AW (2004) SOCS3 is a critical physiological negative regulator of G-CSF signaling and emergency granulopoiesis. Immunity 20: 153-165.

Dalpke A, Heeg K, Bartz H, Baetz A (2008) Regulation of innate immunity by suppressor of cytokine signaling (SOCS) proteins. Immunobiology 213: 225-235.

Dhondt A, Vanholder R, Van Biesen W, Lameire N (2000) The removal of uremic toxins. Kidney Int Suppl 76: S47-59.

Dinarello CA (1997) Role of pro- and anti-inflammatory cytokines during inflammation: experimental and clinical findings. J Biol Regul Homeost Agents 11: 91-103.

Egan PJ, Lawlor KE, Alexander WS, Wicks IP (2003) Suppressor of cytokine signaling- 1 regulates acute inflammatory arthritis and $\mathrm{T}$ cell activation. I Clin Invest 111: 915-924.

Egwuagu CE, Yu CR, Zhang M, Mahdi RM, Kim SJ, Gery I (2002) Suppressors of cytokine signaling proteins are differentially expressed in Th1 and Th2 cells: implications for Th cell lineage commitment and maintenance. J Immunol 168: 3181-3187.

Fujimoto M, Tsutsui H, Xinshou O, Tokumoto M, Watanabe D, Shima Y, Yoshimoto T, Hirakata H, Kawase I, Nakanishi K, Kishimoto T, Naka T (2004) Inadequate induction of suppressor of cytokine signaling-1 causes systemic autoimmune diseases. Int Immunol 16: $303-314$

Galle J, Quaschning T, Seibold S, Wanner C (2003) Endothelial dysfunction and inflammation: what is the link? Kidney Int Suppl S45-49.

Gomez-Guerrero C, Lopez-Franco O, Sanjuan G, Hernandez-Vargas P, Suzuki Y, Ortiz-Munoz G, Blanco J, Egido J (2004) Suppressors of cytokine signaling regulate $F_{c}$ receptor signaling and cell activation during immune renal injury. J Immunol 172: 6969-6977.

Greenhalgh CJ, Metcalf D, Thaus AL, Corbin JE, Uren R, Morgan PO, Fabri LJ, Zhang JG, Martin HM, Willson TA, Billestrup N, Nicola NA, Baca M, Alexander WS, Hilton DJ (2002) Biological evidence that SOCS-2 can act either as an enhancer or suppressor of growth hormone signaling. I Biol Chem 277: 40181-40184.

Greenhalgh CJ, Rico-Bautista E, Lorentzon M, Thaus AL, Morgan PO, Willson TA, Zervoudakis P, Metcalf D, Street I, Nicola NA, Nash AD, Fabri LJ, Norstedt G, Ohlsson C, Flores-Morales A, Alexander WS, Hilton DJ (2005) SOCS2 negatively regulates growth hormone action in vitro and in vivo. J Clin Invest 115: 397-406.

Grimble RF (2002) Inflammatory status and insulin resistance. Curr Opin Clin Nutr Metab Care 5: 551-559.

Hack CE, Zeerleder S (2001) The endothelium in sepsis: source of and a target for inflammation. Crit Care Med 29: S21-S27.

Hansson GK, Robertson AK, Soderberg-Naucler C (2006) Inflammation and atherosclerosis. Annu Rev Pathol 1: 297-329.

Heine GH, Ulrich C, Seibert E, Seiler S, Marell J, Reichart B, Krause M, Schlitt A, Kohler H, Girndt M (2008) CD14(++)CD16+ monocytes but not total monocyte numbers predict cardiovascular events in dialysis patients. Kidney Int 73: 622-629.

Hernandez-Vargas P, Lopez-Franco O, Sanjuan G, Ruperez M, OrtizMunoz G, Suzuki Y, Aguado-Roncero P, Perez-Tejerizo G, Blanco J, Egido J, Ruiz-Ortega M, Gomez-Guerrero C (2005) Suppressors of cytokine signaling regulate angiotensin II-activated Janus kinasesignal transducers and activators of transcription pathway in renal cells. J Am Soc Nepbrol 16: 1673-1683.

Himmelfarb J, McMonagle E, McMenamin E (2000) Plasma protein thiol oxidation and carbonyl formation in chronic renal failure. Kidney Int 58: 2571-2578.

Kamura T, Sato S, Haque D, Liu L, Kaelin WG Jr, Conaway RC, Conaway JW (1998) The Elongin BC complex interacts with the con- served SOCS-box motif present in members of the SOCS, ras, WD40 repeat, and ankyrin repeat families. Genes Dev 12: 3872-3881.

Kario E, Marmor MD, Adamsky K, Citri A, Amit I, Amariglio N, Rechavi G, Yarden Y (2005) Suppressors of cytokine signaling 4 and 5 regulate epidermal growth factor receptor signaling. J Biol Chem 280: 7038-7048

Kato A, Odamaki M, Takita T, Maruyama Y, Kumagai H, Hishida A (2002) Association between interleukin-6 and carotid atherosclerosis in hemodialysis patients. Kidney Int 61: 1143-1152.

Kimura A, Kinjyo I, Matsumura Y, Mori H, Mashima R, Harada M, Chien KR, Yasukawa H, Yoshimura A (2004) SOCS3 is a physiological negative regulator for granulopoiesis and granulocyte colonystimulating factor receptor signaling. J Biol Chem 279: 6905-6910.

Krebs DL, Hilton DJ (2001) SOCS proteins: negative regulators of cytokine signaling. Stem Cells 19: 378-387.

Krebs DL, Uren RT, Metcalf D, Rakar S, Zhang JG, Starr R, De Souza DP, Hanzinikolas K, Eyles J, Connolly LM, Simpson RJ, Nicola NA, Nicholson SE, Baca M, Hilton DJ, Alexander WS (2002) SOCS-6 binds to insulin receptor substrate 4, and mice lacking the SOCS-6 gene exhibit mild growth retardation. Mol Cell Biol 22: 4567-4578.

Krebs DL, Metcalf D, Merson TD, Voss AK, Thomas T, Zhang JG, Rakar S, O’Bryan MK, Willson TA, Viney EM, Mielke LA, Nicola NA, Hilton DJ, Alexander WS (2004) Development of hydrocephalus in mice lacking SOCS7. Proc Natl Acad Sci USA 101: 1544615451.

Kwak BR, Mulhaupt F, Mach F (2003) Atherosclerosis: anti-inflammatory and immunomodulatory activities of statins. Autoimmun Rev 2: 332-338.

Lang R, Pauleau AL, Parganas E, Takahashi Y, Mages J, Ihle JN, Rutschman R, Murray PJ (2003) SOCS3 regulates the plasticity of gp130 signaling. Nat Immunol 4: 546-550.

Leon ML, Zuckerman SH (2005) Gamma interferon: a central mediator in atherosclerosis. Inflamm Res 54: 395-411.

Levey AS, Beto JA, Coronado BE, Eknoyan G, Foley RN, Kasiske BL, Klag MJ, Mailloux LU, Manske CL, Meyer KB, Parfrey PS, Pfeffer MA, Wenger NK, Wilson PW, Wright JT Jr (1998) Controlling the epidemic of cardiovascular disease in chronic renal disease: what do we know? What do we need to learn? Where do we go from here? National Kidney Foundation Task Force on Cardiovascular Disease. Am J Kidney Dis 32: 853-906.

Levy DE, Darnell JE Jr (2002) Stats: transcriptional control and biological impact. Nat Rev Mol Cell Biol 3: 651-662.

Levy DE, Lee CK (2002) What does Stat3 do? J Clin Invest 109: 1143 1148.

Li S, Chen S, Xu X, Sundstedt A, Paulsson KM, Anderson P, Karlsson S, Sjogren HO, Wang P (2000) Cytokine-induced Src homology 2 protein (CIS) promotes $\mathrm{T}$ cell receptor-mediated proliferation and prolongs survival of activated T cells. I Exp Med 191: 985-994.

Libby P (2002) Inflammation in atherosclerosis. Nature 420: 868-874.

Lin JJ, Tonshoff B, Bouriquet N, Casellas D, Kaskel FJ, Moore LC (1998) Insulin-like growth factor-I restores microvascular autoregulation in experimental chronic renal failure. Kidney Int Suppl 67: S195-S198.

Locatelli F, Canaud B, Eckardt KU, Stenvinkel P, Wanner C, Zoccali $C$ (2003) Oxidative stress in end-stage renal disease: an emerging threat to patient outcome. Nephrol Dial Transplant 18: 1272-1280.

Losman JA, Chen XP, Hilton D, Rothman P (1999) Cutting edge: SOCS-1 is a potent inhibitor of IL-4 signal transduction. I Immunol 162: $3770-3774$.

Mansell A, Smith R, Doyle SL, Gray P, Fenner JE, Crack PJ, Nicholson SE, Hilton DJ, O’Neill LA, Hertzog PJ (2006) Suppressor of cytokine signaling 1 negatively regulates Toll-like receptor signaling by mediating Mal degradation. Nat Immunol 7: 148-155.

Marine JC, McKay C, Wang D, Topham DJ, Parganas E, Nakajima H, Pendeville H, Yasukawa H, Sasaki A, Yoshimura A, Ihle JN (1999) SOCS3 is essential in the regulation of fetal liver erythropoiesis. Cell 98: 617-627.

Mark AL, Correia ML, Rahmouni K, Haynes WG (2002) Selective leptin resistance: a new concept in leptin physiology with cardiovascular implications. J Hypertens 20: 1245-1250.

Martens N, Uzan G, Wery M, Hooghe R, Hooghe-Peters EL, Gertler A (2005) Suppressor of cytokine signaling 7 inhibits prolactin, growth hormone, and leptin signaling by interacting with STAT5 or STAT3 and attenuating their nuclear translocation. J Biol Chem 280: 13817-13823.

Martin-Malo A, Carracedo J, Ramirez R, Rodriguez-Benot A, Soriano S, Rodriguez M, Aljama P (2000) Effect of uremia and dialysis modality on mononuclear cell apoptosis. J Am Soc Nephrol 11: 936-942.

Mathur S, Devaraj S, Jialal I (2002) Accelerated atherosclerosis, dyslipidemia, and oxidative stress in end-stage renal disease. Curr Opin Nephrol Hypertens 11: 141-147.

Matsumoto A, Seki Y, Kubo M, Ohtsuka S, Suzuki A, Hayashi I, Tsuji K, Nakahata T, Okabe M, Yamada S, Yoshimura A (1999) Suppression of STAT5 functions in liver, mammary glands, and T cells 
in cytokine-inducible $\mathrm{SH} 2$-containing protein 1 transgenic mice. Mol Cell Biol 19: 6396-6407.

Menegatti E, Rossi D, Chiara M, Alpa M, Sena LM, Roccatello D (2002) Cytokine release pathway in mononuclear cells stimulated in vitro by dialysis membranes. Am J Nephrol 22: 509-514.

Miyazaki H, Matsuoka H, Itabe H, Usui M, Ueda S, Okuda S, Imaizumi T (2000) Hemodialysis impairs endothelial function via oxidative stress: effects of vitamin E-coated dialyzer. Circulation 101: 1002-1006.

Mori H, Hanada R, Hanada T, Aki D, Mashima R, Nishinakamura H, Torisu T, Chien KR, Yasukawa H, Yoshimura A (2004) Socs3 deficiency in the brain elevates leptin sensitivity and confers resistance to diet-induced obesity. Nat Med 10: 739-743.

Naka T, Matsumoto T, Narazaki M, Fujimoto M, Morita Y, Ohsawa Y, Saito H, Nagasawa T, Uchiyama Y, Kishimoto T (1998) Accelerated apoptosis of lymphocytes by augmented induction of Bax in SSI-1 (STAT-induced STAT inhibitor-1) deficient mice. Proc Natl Acad Sci USA 95: 15577-15582.

Nakagawa R, Naka T, Tsutsui H, Fujimoto M, Kimura A, Abe T, Seki E, Sato S, Takeuchi O, Takeda K, Akira S, Yamanishi K, Kawase I, Nakanishi K, Kishimoto T (2002) SOCS-1 participates in negative regulation of LPS responses. Immunity 17: 677-687.

Nicholson SE, De Souza D, Fabri LJ, Corbin J, Willson TA, Zhang JG, Silva A, Asimakis M, Farley A, Nash AD, Metcalf D, Hilton DJ, Nicola NA, Baca M (2000) Suppressor of cytokine signaling-3 preferentially binds to the SHP-2-binding site on the shared cytokine receptor subunit gp130. Proc Natl Acad Sci USA 97: 64936498.

Niemand C, Nimmesgern A, Haan S, Fischer P, Schaper F, Rossaint R, Heinrich PC, Muller-Newen G (2003) Activation of STAT3 by IL-6 and IL-10 in primary human macrophages is differentially modulated by suppressor of cytokine signaling 3. I Immunol 170: 3263-3272.

Novak U, Marks D, Nicholson SE, Hilton D, Paradiso L (1999) Differential ability of SOCS proteins to regulate IL-6 and CSF-1 induced macrophage differentiation. Growth Factors 16: 305-314.

Ortiz-Munoz G, Martin-Ventura JL, Hernandez-Vargas P, Mallavia B, Lopez-Parra V, Lopez-Franco O, Munoz-Garcia B, Fernandez-Vizarra P, Ortega L, Egido J, Gomez-Guerrero C (2009) Suppressors of cytokine signaling modulate JAK/STAT-mediated cell responses during atherosclerosis. Arterioscler Thromb V asc Biol 29: 525-531.

Raj DS, Dominic EA, Pai A, Osman F, Morgan M, Pickett G, Shah VO, Ferrando A, Moseley P (2005) Skeletal muscle, cytokines, and oxidative stress in end-stage renal disease. Kidney Int 68: 2338-2344.

Rastmanesh MM, Bluyssen HA, Joles JA, Boer P, Willekes N, Braam B (2008) Increased expression of SOCS3 in monocytes and SOCS1 in lymphocytes correlates with progressive loss of renal function and cardiovascular risk factors in chronic kidney disease. Eur J Pharmacol 593: 99-104.

Rastmanesh MM, Braam B, Joles JA, Boer P, Bluyssen HA (2009) Increased SOCS expression in peripheral blood mononuclear cells of end stage renal disease patients is related to inflammation and dialysis modality. Eur I Pharmacol 602: 163-167.

Roberts MA, Hare DL, Ratnaike S, Ierino FL (2006) Cardiovascular biomarkers in CKD: pathophysiology and implications for clinical management of cardiac disease. Am J Kidney Dis 48: 341-360.

Robertson AK, Hansson GK (2006) T cells in atherogenesis: for better or for worse? Arterioscler Thromb V asc Biol 26: 2421-2432.

Roelfsema V, Clark RG (2001) The growth hormone and insulin-like growth factor axis: its manipulation for the benefit of growth disorders in renal failure. J Am Soc Nephrol 12: 1297-1306.

Roob JM, Khoschsorur G, Tiran A, Horina JH, Holzer H, WinklhoferRoob BM (2000) Vitamin E attenuates oxidative stress induced by intravenous iron in patients on hemodialysis. J Am Soc Nephrol 11: 539-549.

Rui L, Yuan M, Frantz D, Shoelson S, White MF (2002) SOCS-1 and SOCS-3 block insulin signaling by ubiquitin-mediated degradation of IRS1 and IRS2. J Biol Chem 277: 42394-42398.

Saadeddin SM, Habbab MA, Ferns GA (2002) Markers of inflammation and coronary artery disease. Med Sci Monit 8: RA5-RA12.

Sasaki A, Yasukawa H, Shouda T, Kitamura T, Dikic I, Yoshimura A (2000) CIS3/SOCS-3 suppresses erythropoietin (EPO) signaling by binding the EPO receptor and JAK2. J Biol Chem 275: 2933829347.

Schaefer F, Chen Y, Tsao T, Nouri P, Rabkin R (2001) Impaired JAKSTAT signal transduction contributes to growth hormone resistance in chronic uremia. J Clin Invest 108: 467-475.

Schnackenberg CG (2002) Oxygen radicals in cardiovascular-renal disease. Curr Opin Pharmacol 2: 121-125.

Seki Y, Hayashi K, Matsumoto A, Seki N, Tsukada J, Ransom J, Naka T, Kishimoto T, Yoshimura A, Kubo M (2002) Expression of the suppressor of cytokine signaling-5 (SOCS5) negatively regulates IL4-dependent STAT6 activation and Th2 differentiation. Proc Natl Acad Sci USA 99: 13003-13008.

Sester U, Sester M, Hauk M, Kaul H, Kohler H, Girndt M (2000) Tcell activation follows Th1 rather than Th2 pattern in haemodialysis patients. Nephrol Dial Transplant 15: 1217-1223.
Shouda T, Yoshida T, Hanada T, Wakioka T, Oishi M, Miyoshi K, Komiya S, Kosai K, Hanakawa Y, Hashimoto K, Nagata K, Yoshimura A (2001) Induction of the cytokine signal regulator SOCS3/CIS3 as a therapeutic strategy for treating inflammatory arthritis. J Clin Invest 108: 1781-1788.

Starr R, Metcalf D, Elefanty AG, Brysha M, Willson TA, Nicola NA, Hilton DJ, Alexander WS (1998) Liver degeneration and lymphoid deficiencies in mice lacking suppressor of cytokine signaling-1. Proc Natl Acad Sci USA 95: 14395-14399.

Stenvinkel P (2002) Inflammation in end-stage renal failure: could it be treated? Nephrol Dial Transplant 17 (Suppl 8): 33-38; discussion p 40.

Stenvinkel P, Barany P (2002) Anaemia, rHuEPO resistance, and cardiovascular disease in end-stage renal failure; links to inflammation and oxidative stress. Nephrol Dial Transplant 17 (Suppl 5): 32-37.

Stenvinkel P, Pecoits-Filho R, Lindholm B (2003) Coronary artery disease in end-stage renal disease: no longer a simple plumbing problem. J Am Soc Nepbrol 14: 1927-1939.

Suzuki A, Hanada T, Mitsuyama K, Yoshida T, Kamizono S, Hoshino T, Kubo M, Yamashita A, Okabe M, Takeda K, Akira S, Matsumoto S, Toyonaga A, Sata M, Yoshimura A (2001) CIS3/SOCS3/SSI3 plays a negative regulatory role in STAT3 activation and intestinal inflammation. $J$ Exp Med 193: 471-481.

Takahashi Y, Carpino N, Cross JC, Torres M, Parganas E, Ihle JN (2003) SOCS3: an essential regulator of LIF receptor signaling in trophoblast giant cell differentiation. EMBO J 22: 372-384.

Taleb S, Romain M, Ramkhelawon B, Uyttenhove C, Pasterkamp G, Herbin O, Esposito B, Perez N, Yasukawa H, Van Snick J, Yoshimura A, Tedgui A, Mallat Z (2009) Loss of SOCS3 expression in $\mathrm{T}$ cells reveals a regulatory role for interleukin-17 in atherosclerosis. J Exp Med 206: 2067-2077.

Tang J, Raines EW (2005) Are suppressors of cytokine signaling proteins recently identified in atherosclerosis possible therapeutic targets? Trends Cardiovasc Med 15: 243-249.

Tang J, Kozaki K, Farr AG, Martin PJ, Lindahl P, Betsholtz C, Raines EW (2005) The absence of platelet-derived growth factor-B in circulating cells promotes immune and inflammatory responses in atherosclerosis-prone ApoE ${ }^{-/-}$mice. Am J Pathol 167: 901-912.

Tsirpanlis G (2007) Is inflammation the link between atherosclerosis and vascular calcification in chronic kidney disease? Blood Purif 25: $179-182$

van Guldener C, Janssen MJ, Lambert J, Steyn M, Donker AJ, Stehouwer CD (1998) Endothelium-dependent vasodilatation is impaired in peritoneal dialysis patients. Nephrol Dial Transplant 13: 1782-1786.

van Guldener C, Stam F, Stehouwer CD (2001) Homocysteine metabolism in renal failure. Kidney Int Suppl 78: S234-237.

Wang P, Li N, Li JS, Li WQ (2002) The role of endotoxin, TNF-alpha, and IL-6 in inducing the state of growth hormone insensitivity. World J Gastroenterol 8: 531-536.

Wanner C, Zimmermann J, Schwedler S, Metzger T (2002) Inflammation and cardiovascular risk in dialysis patients. Kidney Int Suppl 99-102.

Wesemann DR, Dong Y, O'Keefe GM, Nguyen VT, Benveniste EN (2002) Suppressor of cytokine signaling 1 inhibits cytokine induction of CD40 expression in macrophages. J Immunol 169: 2354-2360.

Wesoly J, Szweykowska-Kulinska Z, Bluyssen HA (2007) STAT activation and differential complex formation dictate selectivity of interferon responses. Acta Biochim Pol 54: 27-38.

Wheatcroft SB, Williams IL, Shah AM, Kearney MT (2003) Pathophysiological implications of insulin resistance on vascular endothelial function. Diabet Med 20: 255-268.

Yamamoto T YH, Koga M, et al. (2007) Lacking the SOCS3 Gene in Macrophages Prevents the Development of Atherosclerosis in ApoE Deficient Mice. Circ J 71: 170.

Yasukawa H, Misawa H, Sakamoto H, Masuhara M, Sasaki A, Wakioka T, Ohtsuka S, Imaizumi T, Matsuda T, Ihle JN, Yoshimura A (1999) The JAK-binding protein JAB inhibits Janus tyrosine kinase activity through binding in the activation loop. EMBO J 18: 13091320.

Yasukawa H, Ohishi M, Mori H, Murakami M, Chinen T, Aki D, Hanada T, Takeda K, Akira S, Hoshijima M, Hirano T, Chien KR, Yoshimura A (2003) IL-6 induces an anti-inflammatory response in the absence of SOCS3 in macrophages. Nat Immunol 4: 551-556.

Yoshimura A, Ohkubo T, Kiguchi T, Jenkins NA, Gilbert DJ, Copeland NG, Hara T, Miyajima A (1995) A novel cytokine-inducible gene CIS encodes an SH2-containing protein that binds to tyrosinephosphorylated interleukin 3 and erythropoietin receptors. EMBO J 14: $2816-2826$

Yoshimura A, Naka T, Kubo M (2007) SOCS proteins, cytokine signalling and immune regulation. Nat Rev Immunol 7: 454-465.

Zhang JG, Metcalf D, Rakar S, Asimakis M, Greenhalgh CJ, Willson TA, Starr R, Nicholson SE, Carter W, Alexander WS, Hilton DJ, Nicola NA (2001) The SOCS box of suppressor of cytokine signaling-1 is important for inhibition of cytokine action in vivo. Proc Natl Acad Sci USA 98: 13261-13265. 